Mikhail S. Bankov

Postgraduate student of the Stroganov Moscow State Art and Industry Academy

Department of Art History and Humanities

e-mail: bankoff3@yandex.ru

Moscow, Russia

ORCID 0000-0003-2414-8221

DOI: 10.36340/2071-6818-2021-17-4-29-48

\title{
TO THE QUESTION OF SPACE ORGANIZATION OF BOOK ILLUMINATION OF LATE ANTIQUITY AND EARLY MIDDLE AGES (IV - VII CENTURY)
}

Summary: The article focuses on peculiarities of spatial organization of book miniature paintings of late antique and early medieval manuscripts (IV - VII centuries). The author analyses the problem of conveying illusion of depth in illustration in context of gradual transmission from roll to codex, which took place in antique book culture between the II and the $V$ centuries. By analyzing survived fragments of illuminated rolls author displays characteristic features of their spatial organization and observes influence which had tradition of roll illustration on the development of codex. Nevertheless, precisely the miniatures of the codices that have come down to our time are in focus of the author's attention. The stages of development of the text page, the peculiarities of interaction of text and images in codices are compared with the principles of space organization in miniatures. The article makes an attempt, relying on the monuments that have survived to our time, to consider the development of spatial constructions in the period of late Antiquity and early Middle Ages as a continuous process of evolution of the language of book painting. The author assumes that the development of spatial constructions in miniature painting does not imply sharp breaks or regression. Each new stage of the evolution arises from the previous one and

The art of the period of transition from the late Antiquity to the Middle Ages was an extremely important stage in the development of European culture. At this time the foundations of medieval art were laid. This era was of particular importance for the art of book miniature. During this period, such process of exceptional importance as the formation of the codex took place as well as the development of the fundamental principles of interaction of text and images in the book. Such an intensive development of the book art in the transitional era makes the issue of organizing space in late antique minia- makes it possible to expand the arsenal of artistic means which are necessary for solving artistic problems of the time. In accordance with this approach, the article concentrates not only on compositions in which a spatial illusion is created, but also miniatures that are in character more plane. As a result, the author reveals the main types of spatial constructions, considering all surviving monuments of miniature painting of that time. For each type of space organization, the author identifies the basic principles and artistic techniques that allow the artist to convey a sense of depth on the plane of page. The author pays special attention to the comparison of illusionistic tendencies in the late antique book miniature and "reverse perspective", features of which are present in the monuments of the era. The author casts doubt on the need for a sharp contrast between these two approaches to space organization in the monuments of book miniatures of the era. He analyzes the reasons for the appearance of such features of space organization in miniature paintings of late antique and early medieval manuscripts, which are so important for the formation of artistic language of medieval book illumination.

Keywords: spatial constructions, reverse perspective, Antiquity, Middle Ages, book miniatures.

tures especially significant. Several highly respected scientists have touched upon this topic in their treatises. Nevertheless, the study of spatial constructions in the monuments of the book art for a long time was of a selective nature. The researchers focused mainly on miniatures inherited the traditions of antique illusionism. On the contrary, the principles of space organization in the compositions with no illusion of depth remained for a long time "outside the brackets" of art historian research. Studies of spatial constructions in the medieval painting of the 20th century, to which Russian scientists have 


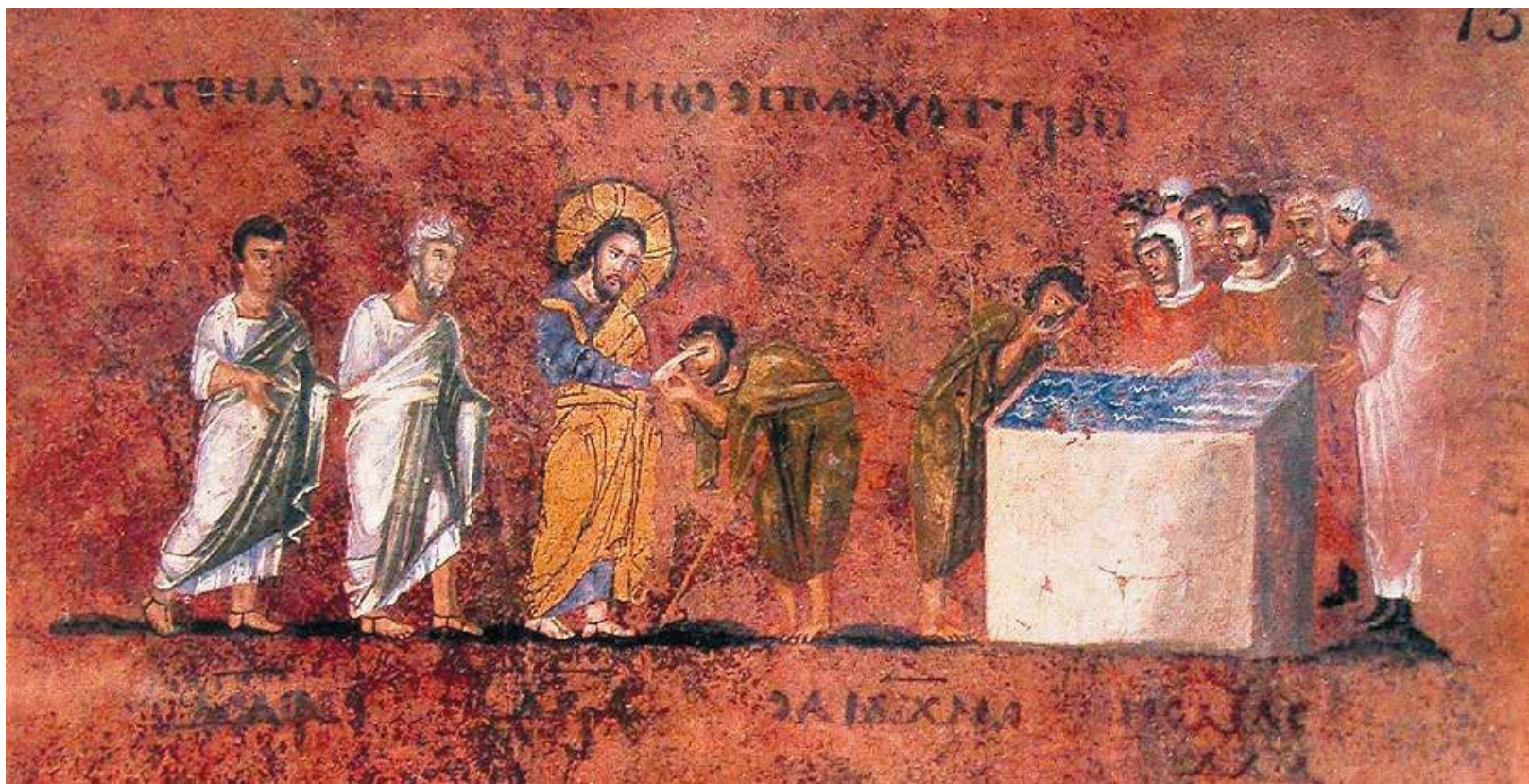

IIl. 1. Museo Diocesano di Arte Sacra di Rossano, Codex Rossanensis, folio 13 r.

made a significant contribution, allow relying on the preserved monuments to define a single line of logic of spatial constructions development in the late antique book miniature and highlight the main types of space organization in illustrations. This is the goal of this article.

The rise of the book miniature art in the late antique period related, according to the researchers, to the emergence of a new text medium which technical features also provided new opportunities for artists ${ }^{1}$. It is a question of the gradual transition from the papyrus roll to the parchment codex which took place between the 2 nd and 5 th centuries $A D^{2}$. Nevertheless, until the 3 rd -4 th centuries, the papyrus roll still remained to be the principal text medium. It is known that in the Antiquity there was a tradition of roll illustration dating back to the Egyptian manuscripts ${ }^{3}$. The surviving fragments of illustrated papyri, the earliest of which dates back to the 2-d century $B C^{4}$, give the opportunity to suggest that illustrations of ancient rolls were located directly inside narrow text columns. The miniature literally interrupts the text and offers a visual equivalent to the part of the narrative next to which the illustra-

1 Andre Grabar et Carl Nordenfalk. - Le haut moyen age du quatrieme au onzieme siecle. Geneve, Skira, 1957; $\mathrm{K}$
Weitzmann, Illustraitions in Roll and Codex, Princeton University Press, 1970, p. 57

K. Weitzmann, Illustraitions in Roll and Codex, Princeto

University Press, 1970., p. 69-70.

Ibid, p. 59 and late

University Press, 1970., p. 49 tion is located 5 . The "papyrus style of illustrated rolls compositions was reproduced in codices during several centuries and significantly influenced the development of the art of book design. Certain features of space organization correspond to this type of miniatures.

An important peculiarity of roll illustrations is that the images are located directly on the surface of the papyrus sheet. This way, the action develops without any spatial environment. Most likely, this is due to the technical feature of the medium: the constant need to fold the papyrus would inevitably lead to damaging the image and, ultimately, to its destruction? ${ }^{7}$. At the same time, the arrangement of the miniatures directly on the plane of sheet, likewise text elements, strengthens the connection between text and image. The fact that the action of illustration develops horizontally from left to right emphasizes the connection between narrative and its visual equivalent. The focus of the artist's attention is on the images of characters which, like words in a text, are combined into a non-verbal narration.

The location of images and text in a common field entails a specific subordination of the image to the surface of the sheet. As a result, the illustration acquires planar character. It is interesting, that such an attitude to depiction is the opposite of the

5 The illustration format, consequently, depends on the size of the text column, most of all, on its width

scientific

University Press, 1970, p. 52-53.

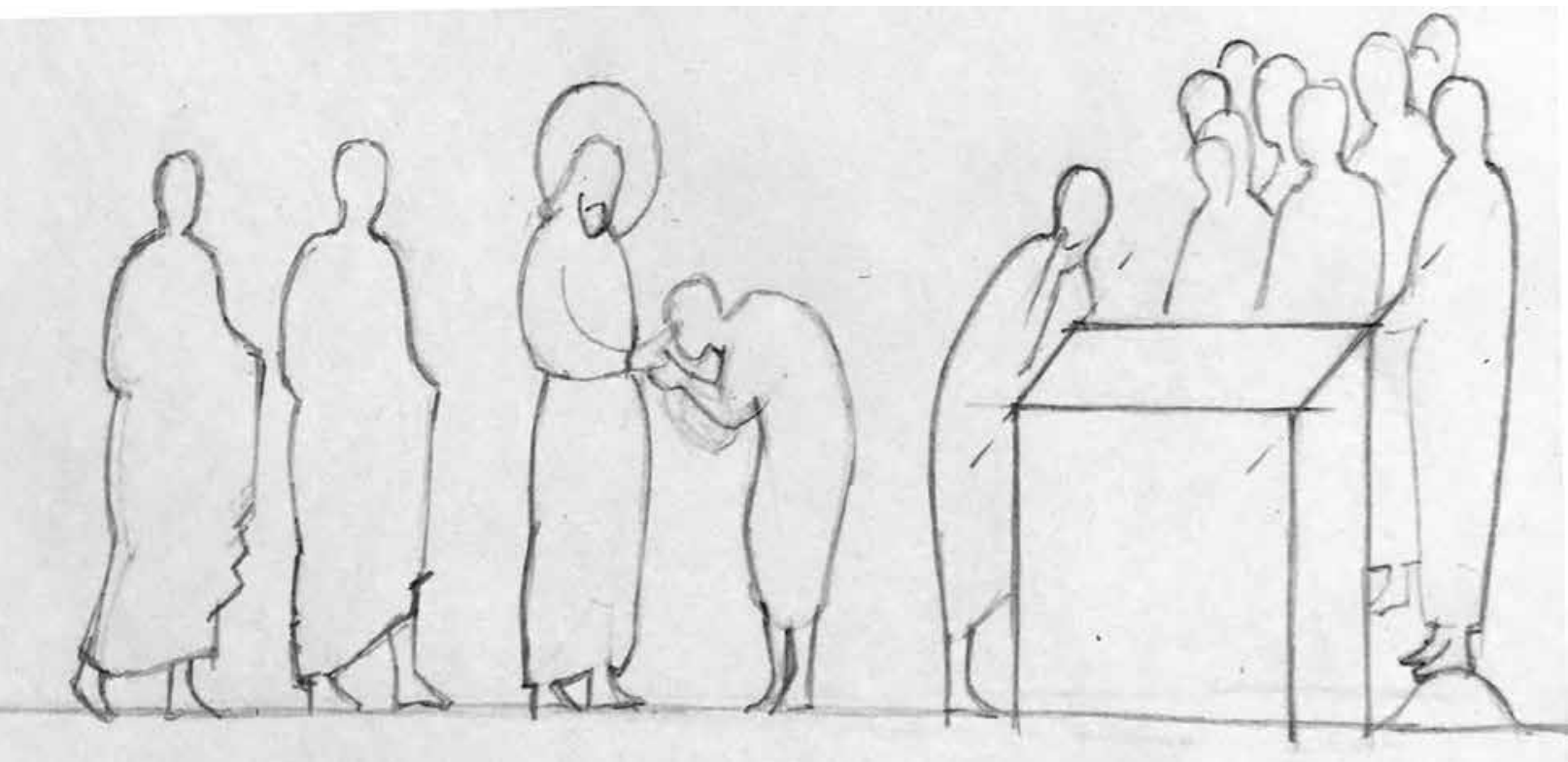

III. 2. Codex Rossanensis, folio 13 r, drawing.

development of illusionistic tendencies in antique monumental fresco painting ${ }^{8}$. It can be assumed that the close connection between text and image in roll illumination requires that the illustration "main tains" visually the solidity of the sheet surface. It is also understandable that there is no treatment of light and shade in the representation of a body which would violate the integrity of the sheet surface "weighing upon" and breaking it. On the contrary, the planar character of the images perfectly corresponds to the requirement of preserving and manifestation of the plane of the sheet.

However, the planar nature of images and the absence of the environment does not mean the absence of certain spatial relationships in the compositions. Thus, a very important artistic mean of constructing space in roll illustrations is the method of "superimposition" of one image on another. By showing one figure overlapping the other, the artist demonstrates the presence of several spatial plans in the composition. A good example of utilization of this technique is a fragment of a miniature with a group of horsemen from the Johnson Collection (4th-5th centuries). Here two spatial plans appear due to the fact that the horsemen located below overlay the figures located above.

The method of superimposition is closely related to another technique which we can designate as the "vertical displacement" method. The essence of this artistic mean is that one image is slightly re-

8 K. Weitzmann, Illustraitions in Roll and Codex, Princeton 9 Bauerische Staatsbibliotek, Munchen, gr. mon. 138. moved vertically with respect to the other image. As we know, an object located closer to a person on the retina of his eye is placed lower than the same object located further away. The ancient artists reproduce this vertical displacement of images on the plane of sheet as an artistic method which indicates the spatial relationship between the depicted figures. As an example of utilization of this method we can mention an illustrated fragment of a parchment roll from the Bavarian State Library (IV century AD) ${ }^{9}$. According to Kurt Weitzmann, the drawing appears to be an illustration for the Iliad. It depicts the moment when Talfibius and Eurybatus lead Brizeis away from Achilles. The artist places one of the accompanying men lower than the other two figures. Thus, the master disposes one personage in the foreground and removes the others to the background creating in such a way two spatial plans.

The examples above allow us to assert that the specific spatial relationships characteristic of the "papyrus style" were elaborated in the ancient roll illustrations. The arro conveying space in the true sense of the word provides a system of plans which indicate spatial exfoliation in the composition. This system has bee used in several late antique codices that have come down to us in which artists reproduce the same type of space constructions. 
One of the surviving manuscripts is the so-called Sinope Gospels from the National Library of France (6th century) ${ }^{10}$. On the folio $29 \mathrm{r}$ a scene of the healing of a blind man by Christ is represented. As in roll illustrations, the action develops along the horizontal axis. The figures of the Saviour and the other characters are united by a barely noticeable thin ground surface line. The author represents the images in a planar manner: the legs and feet of the characters, resting on the ground surface line, are depicted in profile, while the torsos are deployed to the front. Nevertheless, in the miniature painting as well as in the fragments of illustrated rolls, there is an indication of spatial relationships between the characters. The master also uses the technique of "superimposition": the figure of one blind man overlaps the figure of the other as well as one of Christ's followers hides behind the others, so that we can only see his head. Thus, the miniature of the Sinope Gospels reproduces the system of spatial plans characteristic of roll illustrations.

An important tendency of papyrus style miniatures in codices is the appearance and the development of the ground surface line uniting the figures in the composition. So, while in the Sinope Gospels the representation of the ground surface is just an abstract line, in the scene of the resurrection of Lazarus in the miniature of the folio 1 of the Rossano Gospels (6th century) ${ }^{11}$ the line is much less abstract. The artist reproduces the surface irregularities depicting how the basic line of the earth transforms into the image of a rock with the tomb. Thus, we can speak about gradual development of the spatial layer, still rather abstract, which unifies the space of the environment. This tendency is even more noticeable in the lower register of the miniature of the folio 16 of the same Rossano Gospels where the basic line resembles a hilly surface of the earth presented as in a "sectional view".

However, we have to lay stress upon the fact that at this stage the line still remains only a sign of the ground surface. Likewise the horizontal line drawn by the scribes in order to maintain the unity of the string, the ground surface line combines the images of the composition into a narrative. The lat antique artist focuses on the visualization of this narrative, his main goal is to transfer the necessary

10 Bibliothèque nationale de France, Manuscrits occidentaux

suppl. grec 1286, I
Museo Diocesano di Arte Sacra di Rossano, Codex Rossanen-

sis information for understanding of the development of the plot, of the characters and the objects around them. In certain cases, the principle of visualization of the narrative requires the master to reproduce the depth of the particular objects which are most commonly buildings or some kind of architecture. This leads to a contradiction between the horizontal ground surface line uniting the images, the general planar nature of the composition, on the one hand, and the demands of the principle of visualization of the narrative, on the other. In such cases, masters are faced with the difficult task of combining these two contradictory moments.

One of the ways for solving this problem is to combine different points of view in the representation of an object. This way, in the miniature of the folio 13 of the Rossano Gospels (Fig. 1, 2.) dedicated to the healing of a blind man the artist represents "the Pool of Siloam" as a parallelepiped. The artist depicts the upper part of the bath from a higher point of view drawing it in accordance with the principles of axonometry. The most probable purpose for reproducing the depth of the pool is to demonstrate the surface of water which is necessary for visualizing the function of the object in the story. At the same time, all other images of the composition are subordinated to the principle of planeness developing along a horizontal ground surface line. Thus therefore, in order to underline the stability of the parallelepiped, the artist depicts its lower part in planar manner leaning on the same horizontal line. For that the master disproportionately, as it seems, lengthens the distant part of the side of the pool. Thus, the artist combining several perspectives re produces the volume of the object and, at the same time, lines up all the images on one horizontal line. This way the plane of the sheet is not disturbed. Such artistic techniques of space construction become more and more frequent since the 6th century.

Another way is to attach a three-dimensional image to the ground surface line without distortion making, the miniature of the folio $4 v$ of the Vienna Genesis (I half of the 6th century ${ }^{12}$ dedicated to the promise given by God to Abraham about his countless posterity. In the left part of the upper register of the composition, we can see Abraham sleeping on a bed. The master depicts the couch in accordance with the principles of axonometry without distortions. The long side of the parallelepiped develops diagonally, so that the distant edge is removed upwards. The depiction of the sofa should have presupposed, as it seems, a corresponding surface plane depicted from the high point of view. On the contrary, the artist quite mechanically attaches the short side of the bed to the ground surface line, while the long side does not touch it at all. The antic master solves the contradiction that arises between the three-dimensionality of the depicted object caused by the requirements of the principle of visualization of the narrative and the general planar nature of the composition, unlike the previous example, not by distorting the shape of the object. On the contrary, the artist utilizes the coloristic technique of local color patches which visually flattens the depiction of the bed. The volume of the object is guessed but not supported by treatment of light and shade. As a result, the problem is solved: the artist reproduces the three-dimensionality of the bed without violation the solidity of the sheet surface.

This way, the both variants of the solution of the described contradiction presuppose a certain "discontinuity", a violation of the unity of spatial logic within the composition. The artist makes a compromise with these distortions in order to comply with requirements of the most important principle of the visualization of narrative. Analyzing this heterogeneity of the space constructions of late antique miniatures one can recall the thought of E. Panofsky expressed in his article "Perspective as Symbolic Form" about the fundamental discontinuity, unsystematic nature of space in the ancient art ${ }^{13}$. The great German researcher wrote about the ancient compositions in which the illusion of depth was created. However, this principle seems to hold true for the tradition of roll illustration as well.

So, the cited examples of miniatures in rolls and codices allow us to speak about a specific type of space organization characteristic of the illustration of the "papyrus style". The close connection of the miniatures with the text characteristic of this type, on the one hand, determines the planar character of the images and their horizontal development resembling a text line. On the other hand, the necessity to the text in certain cases determines the need to convey the depth by arranging images into a sys

13 E. Panofsky, Perspective as Symbolic Form. Zone Books, New York, p. 42 . tem of spatial plans or by including three-dimensional elements in the composition that nevertheles does not violate the general planar nature of the illustration.

Analyzing spatial constructions in the book miniature of the era of the late Antiquity, one canno fail to mention such an important process, which takes place in the book art, as the gradual emancipation of the illustration from the text column. The system of roll illustrations transferred to the codex is being transformed. Increasing width of the tex column entails the increase of the size of the illus tration. Compositions that have previously existed separately are combined into one scene ${ }^{14}$, sometimes they were even arranged in several levels. The process of the emancipation of the image from the text is closely related to the development of space constructions. For instance, in a number of surviving manuscripts the artists combine two scenes located one above the other by widening of the ground surface line. A suitable example of such unification is the miniature of the folio $9 r$ (Fig. 3.) of the Vienna Genesis. In spite of a little bit mechanical character of the integration of the two scenes separated in time and space, we can note that the basic line turns here into a surface on which the personages are located. The next important step on the path of the emancipation of the image from the text is the separation of the image with a frame. This turn the illustration into a detached space free of the dominance of the sheet plane, which visually flatens the image.

Subsequent to this important step is a pictorial treatment of the background. It is important to note that, as Kurt Weitzmann mentioned, this background is treated in a rather planar manner ${ }^{15}$. The illusion of space is created by adding (sometimes quite "mechanically", in the expression of Weitzmann) to the site a flat backdrop which depicts a part of the environment remote from the viewer in a rather abstract manner. Thus, the action takes place in a narrow strip of the spatial layer, on a kind of stage "gripped" between the transparent "screen" of the sheet surface and the flat background reminiscent of theater scenery.

A good example of such an organization of space is the miniatures of the Ambrosian Iliad (late 5th -

14 K. Weitzmann, Illustraitions in Roll and Codex, Princeton University Press, 1970, p. 84.

K. Weitzmann, 1 llustraitions
versity Press, 1970, p. 99. 


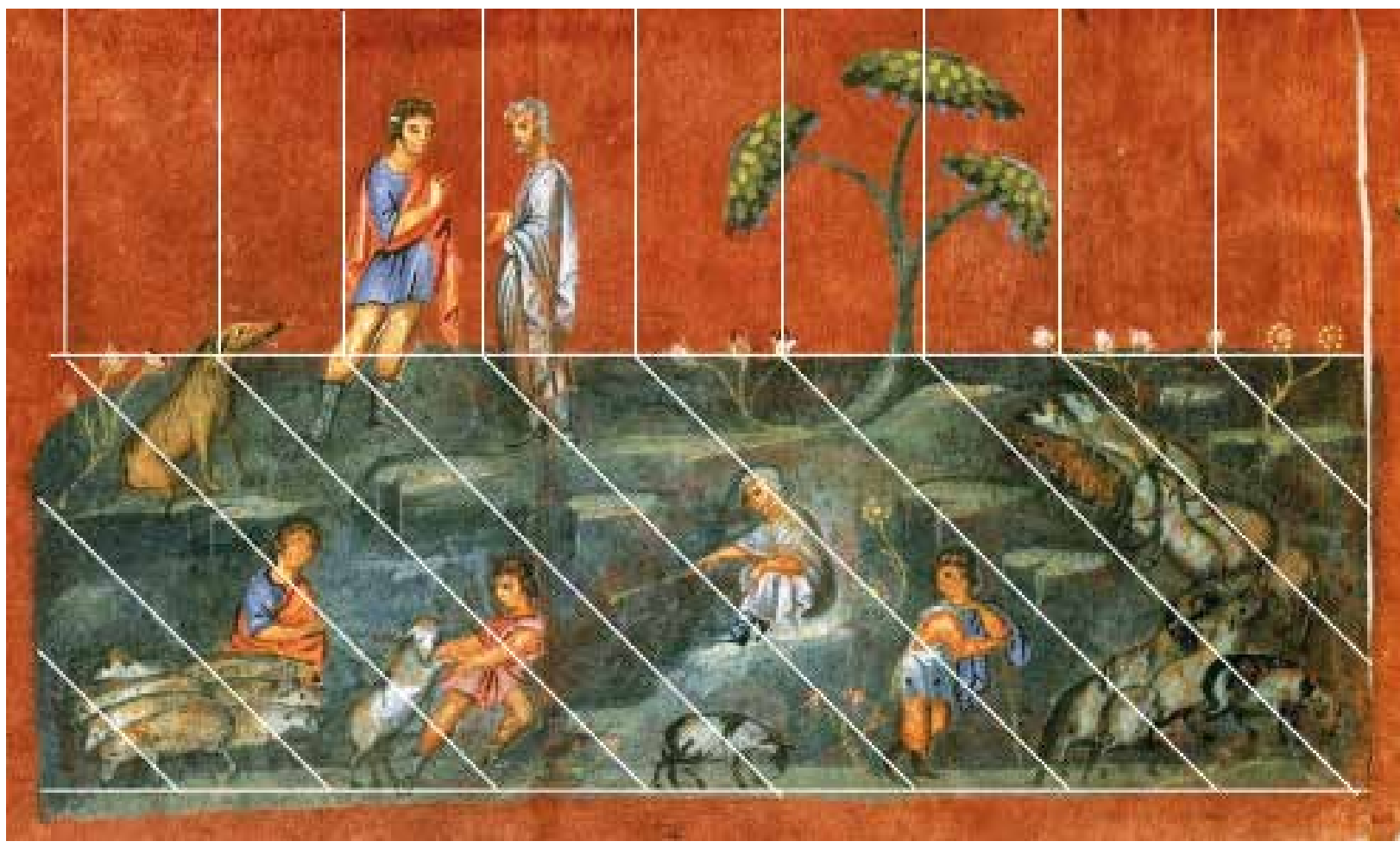

III. 3. Wien, österreichische Nationalbibliothek, Cod. Theol. gr. 31 .
Miniature painting of folio $9 \mathrm{r}$ with a graphic scheme of spatial organization.

early 6 th century $)^{16}$. Folio $42 v$ represents the sacrifice of Achilles (Fig. 4, 5.). The action takes place on the ocher-yellow strip of land. The blue-sky field limits it from behind. This way, due to the separation of the image from the text with a frame, the artist gets the opportunity to form a spatial layer inside the composition. This spatial layer is rather narrow, it is "gripped" between the transparen "screen", which the frame creates, and the flat backdrop resembling a theatrical stage. The impression of the spatiality of the image arises due to the fact that the characters and the objects around them "break away" from the basic horizontal line and find themselves located on the ground surface. However, the ocher-yellow stripe, covered over with one color, by itself, out of connection with the images located on it does not create the impression of spatial dynamics. It is perceived as a foreshortened surface of the ground due to the fact that the position of the anatomically correctly depicted feet of Achilles corresponds to the perspective of the altar. Owing to these details the viewer's eye guesses the movement of the surface on which they are disposed. The fact that the altar is depicted in accordance with principles of axonometry also emphasizes the spatiality of the scene. Here, in contrast to the miniatures of the Vienna Genesis, the master draws

16 Milan, Biblioteca Ambrosiana, Cod. F205inf, Ilias Ambrosiana

all the corresponding facets of the object in parallel to each other, without any distortion. The entire scene is illuminated from a single source: the volume of the hero's figure, of the altar, of the trunks and the foliage of the two small trees next to the altar are conveyed by chiaroscuro. Accordingly, the master emphasizes the stability of their location on the plane by the shadows that they cast.

Such a system of the space organization of book illustrations as a narrow spatial layer will take on fundamental significance for the late antique miniatures in which artists will aspire to convey the illusion of depth. This system first appears at the turn of the 4 th and 5 th centuries ${ }^{17}$. This principle obtain its most eloquent artistic expression in two remarkable monuments which were presumably created in the same workshop - these are the Quedlinburg Itala fragments (early 5 th century) ${ }^{18}$ and the Vatican Virgil (late 4 th - early 5 th century) ${ }^{19}$. A distincanization feature of the miniatures of these magnificent manuscripts is that there is no clear boundary between the strip of the ground surface and the background. So, in the scene of Saul's sacrifice, presented on the folio 2 of the Quedlinburg Itala, the lower yellow-ocher band, on which

17 K. Weitzmann, Illustraitions in Roll and Codex, Princeton University Press, 1970, p.100

18 Staatsbibliothek zu Berlin, Cod. theol. lat. fol. 485. the action of the miniature takes place, is gradualy spilling over to the background. The artist forms it from several color stripes smoothly merging into each other. This technique allows the artist to create an effect resembling the impressionists' "aerial perspective". At the same time, the master does not convey the depth of the space in the proper sense of the word since the background does not contain any hint at the depiction of environment, object contours or the horizon line. Because of this, it is rather difficult to say that the antique artist overcomes the planar solution of the background. Rather the latter resembles picturesque scenery which conveys spatial dynamics into the depth but still remains flat itself.

It should be noted that the authors of the illusionistic miniatures of the two magnificent manuscripts solved very diverse spatial problems. The series of the miniatures of the Vatican Virgil contains the representations of interiors as, for instance, the scene of Dido's death on the folio 41r. In the interior compositions (folio 40r and 41r) the artist depicts the ceiling in a characteristic "antique" perspective: the parallel straight lines converge in respect to each other, but do not go to a single vanishing point ${ }^{20}$. The same manuscript contains examples of landscapes with panoramic views as in the miniature on the folio 42r. Nevertheless, in all these cases the same spatial system remains: the action unfolds between the screen of the parchment sheet and the flat background.

All in all we can conclude that in the illuminated manuscripts of the end of the Roman Empire there are several instances of creating the illusion of space. The authors of these monuments of the book painting convey the space in accordance with the certain principles. At the same time, these principles are much less rigid than mathematical constructions of the Renaissance perspective. In the late antique miniatures there is no mathematically verified perspective grid which is "superimposed" on the scene and subordinates all elem The antic masters create the illusion of a spatial layer by utilizing several artistic techniques aimed rather at creating the illusion of three-dimensionality of the figures of characters and objects around them than at forming of a rigidly structured space In this regard, one cannot fail to recall once again the thought of Erwin Panofsky about the unsystem

20 E. Panofsky, Perspective as Symbolic Form. Zone Books, New York, p. 38 and late atic nature of space organization in the ancient art. The German researcher notes that there are constant "glitches" in the illusionistic antique compositions. This "discontinuity" of space is connected according to Panofsky, with the fact that the classical art of Antiquity, which laid the foundation no only for the late antique but also the medieval art was "a purely corporeal art ${ }^{21 . "}$ "The era of Hellenism according to Panofsky, expanded the artist's field of vision. The masters began to depict, in addition to the objects, "the surrounding space which unified them". Nevertheless, "the artistic imagination remains attached to individual objects, to such an extent that space was still perceived not as something that could embrace and dissolve the opposition between bodies and nonbodies, but only as that which remains, so to speak, between the bodies ${ }^{22 . "}$

Thus, in the ancient art, the emphasis is shifted to the depiction of the body. Indeed, in the above examples of the illustrations of the late Roman manuscripts, the illusion of space arises due to utilization of certain artistic techniques aimed mainly at the depiction of bodies, objects, the conveying thei positions relative to each other rather than their environment. This principle of aspective, judging by the surviving ancient Roman copies, was characteristic of the monumental painting of the Ancient Greece, but in the book miniatures of the late Antiquity it undergoes its own changes. The focus on the depiction of the image of an individual object the "bodies", makes an impact upon the characte of space constructions. For instance, the arrangement of figures in the spatial layer does not presup poses a strictly defined spatial module which could determine the diminution of the objects while mov ing away from the foreground into the depth of the composition. The size of the objects often does not decrease at all. In this way, in some miniatures of the Vatican Virgil, when it is necessary to show a wide panorama of a city or an entire island as, for example, on the folio $27 r$, the artist expands the plane of the "scene" to the upper edge of the composition. Seemingly, it could be expected that the expansion of the surface plane will make it possible to con vey the active space dynamics into depth. However, the ancient master avoids visual deepening of the space and aspires to maintain a single scale of the depicted objects. The artist represents houses

21 E. Panofsky, Perspective as Symbolic Form. Zone Books, New York, p.
Ibid. 


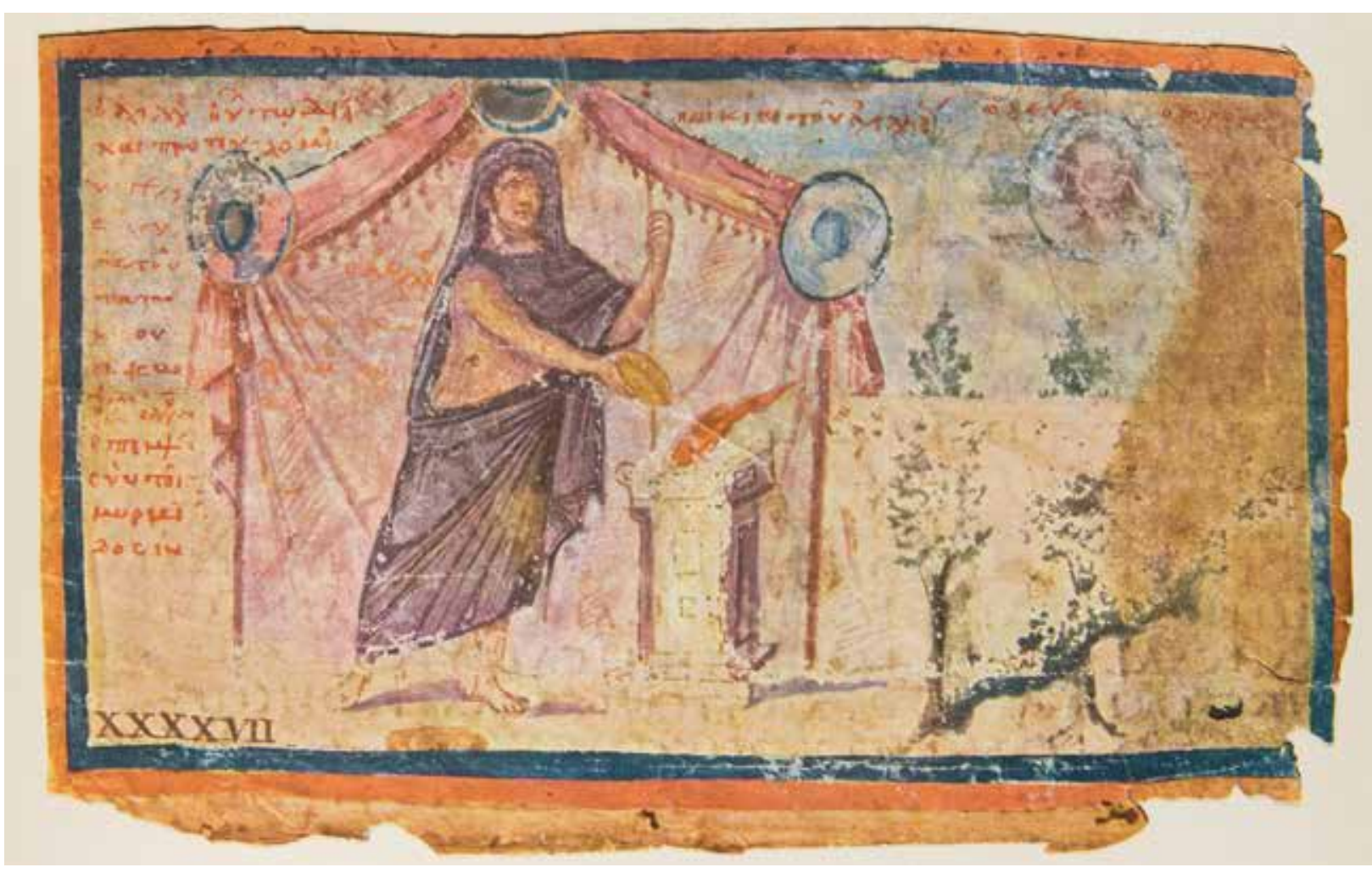

11. 4. Milan, Biblioteca Ambrosiana, Cod. F205inf, llias Ambrosiana, folio 42 v

and walls placed in the upper part of the image and, sional images occurs repeatedly: we may recall the apparently, quite distant from the imaginary viewer on the same scale as those located in the foreground. Thus, the enlargement of the spatial layer does not solve the problem of its depth, it still remains to be narrow.

The concentration of the artist's attention on the depiction of individual objects is closely related to the subjectivity of space constructions which E. Panofsky mentions. In some miniatures of the Vatican Virgil, this subjectivity results in the fact that the certain elements of the compositions are depicted out of the general spatial logic of the miniature painting. A number of Russian researchers consider such "distortions" of images in connection with a desire to depict an object from the most favorable point of view so that to convey the information about it as fully as possible ${ }^{23}$. Indeed, the composition on the folio $17 r$ depicts the sea, the coastline and the isand in the background from a higher point of view one may say, from the top down. At the same time, the master depicts the temple on the island frontally as well as the trees behind it which he arranges on the upper part of the plane outline of the island. The similar combination of planar and three-dimen23 P. Florensky, Works in four volumes, V.3. - M ., 2000, Reverse perspective, pp. 46 - 98., B.V. Rauschenbach Spatial construcUspensky Semiotics of Art — M : School "Languages of Russian Culture", July 1995. miniature of the folio $6 r$ where the lake depicted in a flatly manner destroys the three-dimensional spatial logic of the miniature painting. Also, the subjectivity of space constructions becomes apparen in violations of the unity of scale of the compositional elements. For instance, in the miniature of the folio 19r, the figures of the warriors are disproportionately large in comparison not only with the city walls but also with the Trojan horse.

In this way, the system of space construction elaborated in the late antique illusionistic miniatures was quite flexible and presupposed the certain subjectivity. This subjectivity was gradually increasing since the middle of the 5 th century ${ }^{24}$. Since that time, in the book miniature, a gradual transition had begun from the interpretation of the image as an illusion of tree-dimensional reality created on a plane surface to the image as a pictorial unit which integrates a whole complex of knowledge about the object. In other words, the image summarizes the author's visual impressions separated in time and space. Ac cordingly, the image often combines different points the treatment of light and shade, the shadows cast the correlation between the positions of the figure's 24 K. Weitzmann, Illustraitions in Roll and Codex, Princeton University Press, 1970., p. 56 of view. This makes the depiction more plane. The artistic means aimed at volume conveying such as

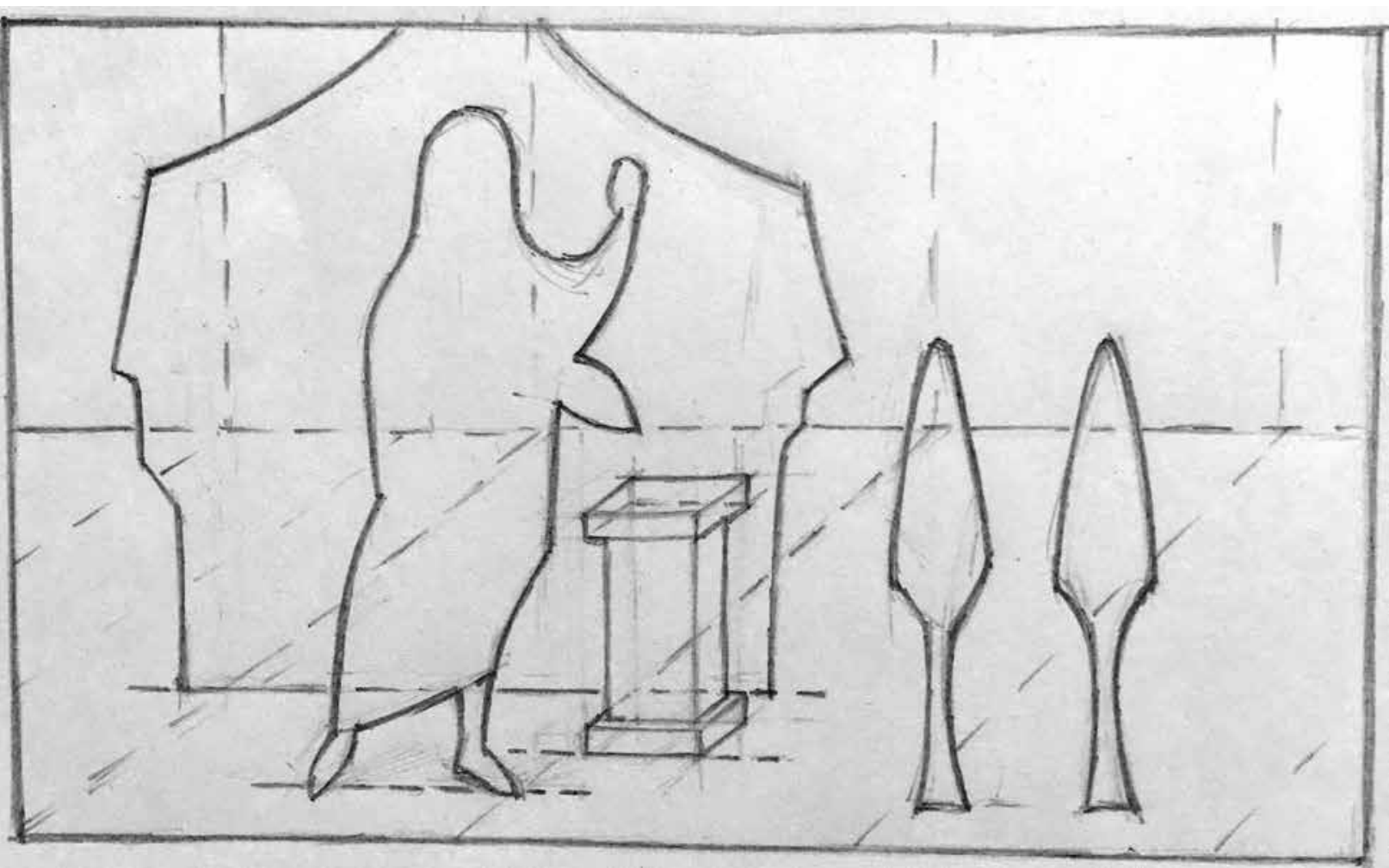

IIl. 5. llias Ambrosiana, folio $42 \mathrm{v}$, graphic scheme of spatial organization.

feet and the perspective of the surface plane - all with the scene of Dido and Aeneas at a feast from these techniques turn out to be unnecessary and the Roman Virgil25, a manuscript from the middle gradually disappear. The outline takes on the spe- of the 5th century in which the features of the trancial significance as a unifying principle combining sition to the new pictorial system appeared for the different perspectives together in one image. The first time. Depicting the central characters of the minapproach to the image as a specific "sum of knowl- iature, the artist combines several different perspecedge" about the object presupposes not only the tives. The author represents the table from a high quest of the most suitable perspective for each of point of view, while the torsos of the characters, on its part but also the facial expressions which most the contrary, are depicted from the front The mascharacteristically reflect the conception of the char- ter represents the faces en face as well, most likely, acter as a whole person, of its inner world. Thus, to create an image of more expressiveness. The authe principle of summarizing visual impressions al- thor aspires to put emphasis on the most significant lows the viewer to receive much more information parts of the body and therefore disproportionally enabout the object than the reproduction of a single larges the personages' heads, eyes, torsos. The desire impression of the object at a given point in time on to convey the most important information about the the pictorial plane. So, in this sense, we can say that depicted body sometimes leads to a kind of "omisthe logic of the development of ancient art is not sion": picturing the left character's arm reaching out interrupted. As with the ancient illusionistic paint- towards the table the master depicts just the hand ing, the artist focuses on the object. The emphasis is and the forearm. Apparently, for the artist it seems to shifted from the subjec

object to a greater objectivity, the desire to depict action. Therefore, the shoulder is left out by the artobject as the artist knows it, and not as it is seen. We can observe the described process on the example of a number of monuments of the transitional period. The development seemingly progressed gradually, at different rates in different regions. It should be noted that the changes affected firstly the manner of the miniature characters' representation. For instance, we may recall the miniature painting ist as an uninformative detail which could come into conflict with the rhythmic unity of the whole miniature painting. These distortions lead to the visual flattening of the images. The manner of the depiction of the characters' garments as color patches covered over with a uniform tint and a linear rhythm of

25 Biblioteca Apostolica Vaticana, Vat.lat.3867. 
folds superimposed above correspond with the planar nature of the images of the illustration.

However, it is important to note that the described "distortions" in the characters' representation do not destroy the basis of the spatial layer system in the composition of the Roman Virgil. The action takes place on the narrow horizontal strip limited by the vertical plane of the wall. Due to the vertical displacement of the compositional elements, a system of plans is created: the figures of the slaves are located closer, in the foreground while the table and the figures of the main characters are disposed in the background. In addition, the images of the servants overlap the depiction of the bed. This feature indicates that the slaves are closer to the position of imaginary viewer, and this, in its turn, visually moves them out to the fore. Thus, we can say that a spatial layer is formed in the miniature of the Roman Virgil. However, the tendency to summarize several visual impressions and the general flattening of images lead to the fact that the sensation of spatial dynamics is significantly weakened.

A significant change in the space organization of book miniatures is the unification of the "stage where the action takes place and the background. In this way, in the Rabbula Gospels (6th century) ${ }^{26}$ on the folio $14 r$ the evangelists surrounding Christ seated on the throne are depicted on a green field which covers the entire miniature likewise a carpet. The artist gives no hint at the border between the horizontal strip of a "stage" and the background. At the same time, the artist implies the opposition between the foreshortened ground surface and the vertical plane of the backdrop indicating it by some methods and details. First of all, the evangelists figures are anatomically proportional, they are illuminated from one point (the shadows cast to the right side of each figure). Then, the characters' feet "stand" on the same plane, that is, they are rotated accordingly to each other in such way that the plane on which the evangelists are located is visually guessed. In addition, the master also utilizes the technique of vertical displacement: the two figures located below are seemingly closer to the imaginary spectator than those that are placed higher. Thus, the author creates an impression that the foreshortened ground surface gradually "flows" into the vertical background and, consequently, forms a kind of a spatial layer in the miniature painting

26 Firenze, Biblioteca Medicea Laurenziana, cod. Plut. I, 56.
At the same time, in another composition of the Rabbula Gospels (folio 1r), the scene of Pentecost the feeling of spatial dynamics within the miniature painting entirely disappears, though the master represents the characters against the same background of green grass. The major cause of the disappearance of the spatial layer in the miniature painting is that the author combines in the composition two different points of view on the scene On the on hand, the master disposes the figures of the apostles along the edge of a circular field which seems to be a kind of piece of ground in the centre of a green field. This creates the impression that we perceive the scene from a high point of view. On the other hand, the figures of the apostles themselves are depicted strictly frontally. All in all, the application of the principle of summarizing visual impression leads to the fact that the characters' figures seem to be "cut out" and glued to the parchment sheet. The depiction of the apostles without any treatment of light and shade, in a planar manner as well as a thick contour line around the images also corresponds with this effect. Certainly, it should be noted that there are certain spatial relationships between the characters of the miniature painting. However they are rather guessed than depicted. The figures of the apostles located below overlap the figures located slightly higher, and this way come to the fore of the miniature

Thus, we may say that in the late antique illustrations of the codices separated from the text by the frame a return to the system of spatial plans has been carried out. In a sense, this process might be considered in context of the general trend in the late antique art noted by Panofsky, the focus on the object depiction sometimes at the expense of the unity of spatial logic. Accordingly, this tendency of the subjective interpretation of images leads to an increase of the subjectivity of space constructions and then to the abandonment of the task of creating the illusion of space at all. To convey spatial relationships between images, it is enough to designate these relationships, point them out but not to represent. To achieve these objectivities the artistic means indicating spatial relations in roll illustrations, the method of "superimposition" and the technique of "vertical displacement", are quite sufficient.

Here are some instances of the late antique miniature paintings organized as a system of spatial plans. Such spatial organization is carried out in on of the small miniatures dedicated to the Passion of

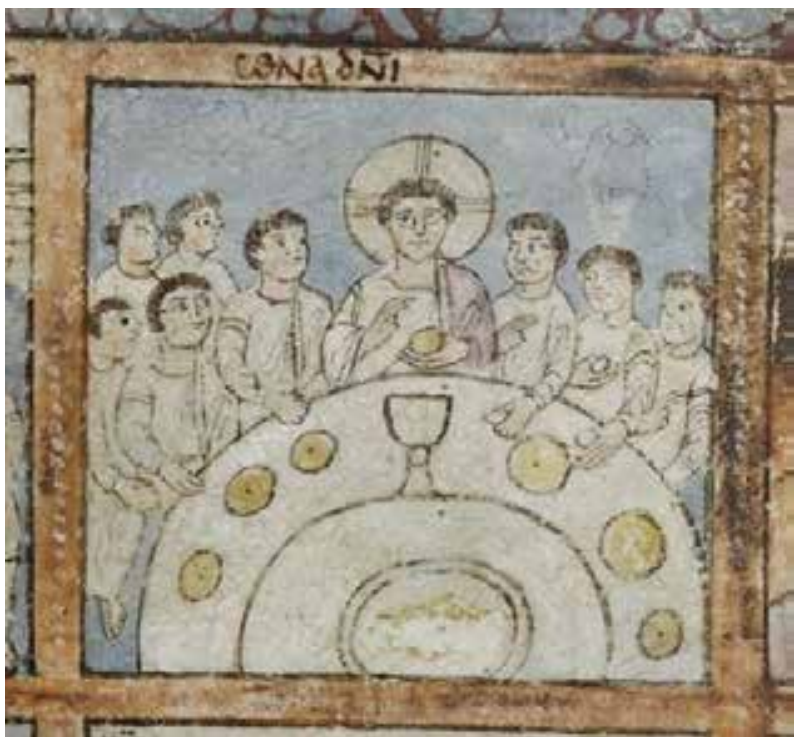

III. 6. Cambrdige, Corpus Christi College, Lib. MS. 286,

Christ on the folio 125r of the St. Augustine Gospels (6th century) ${ }^{27}$, namely the scene of the Las Supper (Fig. 6.). The artist reproduces Christ and the apostles seated at the table. The master combines several perspectives: he represents the characters' figures frontally while the table is depicted from a high point of view. At the same time, the autho creates a system of spatial plans: the round table overlaps the figures of the characters and this way comes to the fore (Fig. 7.). In turn, the master displaces the apostles in two ranks, so that the front figures cover the images of those sitting behind and, therefore, remove them into the background. Another example of a monument, whose miniatures are built in accordance with the principle of spatial plans, is the Ashburnham Pentateuch (6th early 7 th century ${ }^{28}$. In the upper part of the miniature of the folio $65 r$ "Egyptians mourning their first-borns" the characters depicted in planar, rather abstract manner seem to be hovering against the background. The figures have no connection with the plane; they seem to be "cut out" and superimposed on the architectural background that fills the entire

27 Cambrdige, Corpus Christi College, Lib. MS. 286

28 Bibliothèque nationale de France, MS nour. acq lat 2334

REFERENCES:

1. Zhogin, L.F. 1970. The language of the painting, Moscow 5. Grabar, A., Nordenfalk, C. 1957. Le haut moyen age, du 2. Rauschenbach, B.V. 1975. Spatial constructions in ancient Russian painting, Moscow.

3. Uspensky, B.A.1995. Semiotics of Art, Moscow

4. Florensky, P. 2000. Works in four volumes, vol. 3. Reverse perspective, Moscow, pp. 46-98.

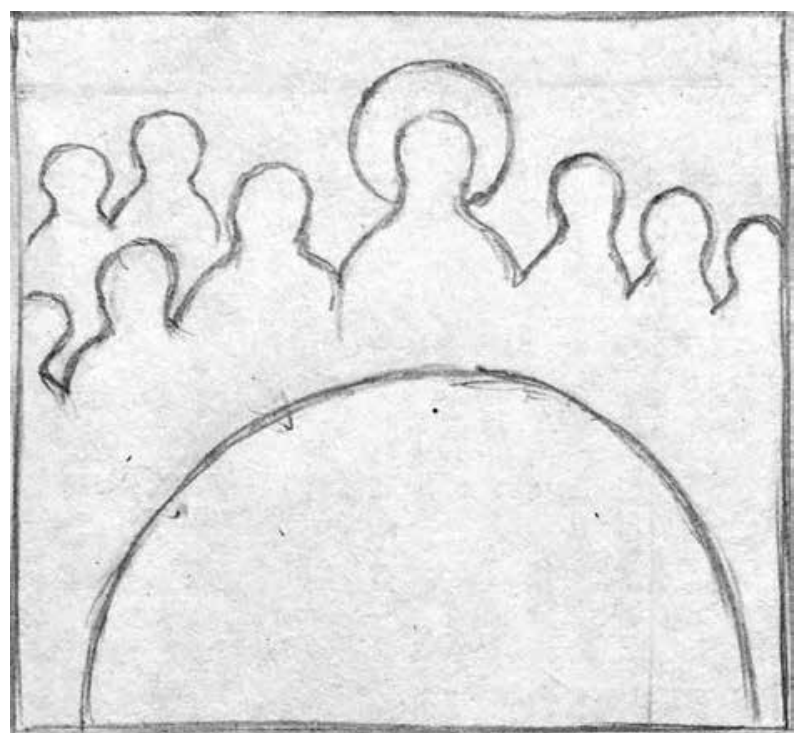

IIl. 7. St. Augustine Gospels, folio 125r, drawing.

miniature. Thus, the two plans are formed, the first where the action takes place, and the second which is an expanded architectural composition indicating the scene of the action. Such a system of severa separate spatial layers will be extremely importan for the medieval miniature painting. In particular, it will be in a demand in book illustrations of the Romanesque epoch which compositions form a complex, multi-stage system of spatial plans ${ }^{29}$.

To sum up, we can conclude that in the late antique book miniature three main types of space construction can be distinguished. Firstly, the tradition of roll illustrations presupposes a planar character of compositions which develop likewise a frieze along a horizontal line Secondly, the appearance of the frame made it possible to create compositions limited, on the one hand, by the plane of the sheet and, on the other, by a flat background. Thirdly, under the influence of the general trend of the late antic art, the miniatures separated from the text by a frame return to the organization of the composition as a system of spatial plans.

29 O. Pächt, Buchmalerei des Mittelalters: eine Einführung, Prestel-Verlag, 1984, S. 43. in which the action develops within a spatial layer
Weitzmann, K. 1970. Illustraitions in Roll and Codex, Princeton University Press, 1970.

Pächt, O. 1984. Buchmalerei des Mittelalters: eine Einfuhrung. Prestel-Verlag, p. 43. 
Михаил Сергеевич Банков

Аспирант Московской государственной художественно-промышленной академии им. С.Г. СТроганова Кафедра истории искусств и гуманитарных наук e-mail: bankoff3@yandex.ru Москва, Россия ORCID 0000-0003-2414-822

DOI: 10.36340/2071-6818-2021-17-4-29-48

\section{К ВОПРОСУ ОРГАНИЗАЦИИ ПРОСТРАНСТВА В КНИЖНОЙ МИНИАТЮРЕ ПОЗДНЕЙ АНТИЧНОСТИ И РАННЕГО СРЕДНЕВЕКОВЬЯ ( IV—VII ВВ.)}

Аннотация: В статье анализируются особенности построения пространства в иллюстрациях рукописей V-VII веков. Проблема передачи глубины на плоскости книжной страницы анализируется в контексте постепенного перехода от свитков к кодексам, который произошёл между II и V веками. Анализируя сохранившиеся фрагменты иллюстрированных свитков, автор выявляет характерные для них особенности организации пространства и рассматривает влияние традиции иллюстрирования свитков на развитие кодекса. Тем не менее именно миниатюры дошедших до нашего времени кодексов находятся в фокусе внимания автора Этапы развития организации текстового пространства, особенности взаимодействия текста и изобрантения о собенности взаимодействия текста и изображения в рукописях сопоставляются с принципами построним пространства в миниатюрах. В статье предпривремени памятники, рассмотреть развитие пространственных построений в период позднй Антостранранны постоенй в период поздней Античности и

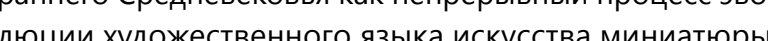
Автор предпоте что развитие пространствн

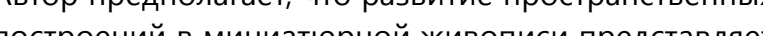
собой собой целостнй процесс, в котором каждый новый арсенал худож ствен и средств, необходим В Аля

решени стояии перед художникани задач. В соот-

Искусство переходного периода от поздней Античности к Средним векам - чрезвычайно важный этап в развитии европейской культуры. В это время закладываются основы средневекового искусства. Особое значение играет эта эпоха для искусства книжной миниатюры. В этот пери од происходит формирование кодекса, основополагающих принципов взаимодействия текста и изображения в пространстве книги. Развитие искусства книги в переходную эпоху делает осо- ветствии с данным подходом в статье анализируются не только композиции, в которых прослеживаетс пространственная иллюзия, но и миниатюры, носящие более плоскостной характер. В результате выявляются основные типы пространственных построений, характерных для всех сохранившихся памятников книжной миниатюры того времени. Для каждого типа формирования пространства автор выявляет базовые принципы, характерные для данного типа художественные приёмы, позволяющие мастеру передать ощущение глубины на плоскости страницы. Особое внимание уделяется автором сопоставлению иллюзионистических тенденций позднеантичной книжной миниатюре и «обратной перспективы», черты которой присутствуют в памятниках эпохи. Автор ставит под сомнение необходимость резкого противопоставления этих двух подходов к организации пространства в памятниках книжной миниатюры эпохи. В статье анализируются причины возникновения в миниатюрах позднеантичных и раннесредневековых рукописей подобтичнх и раннесредневековых рукописей подоб( важных для формиров

Ключевин стова: Пространственнtе построения,

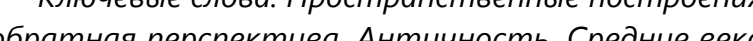
книжная миниатюра.

бенно значимым вопрос об организации пространства в позднеантичных миниатюрах. Это вопрос освещался в исследованиях весьма авторитетных учёных. Тем не менее исследование пространственных построений в памятниках книжного искусства долгое время носило внбороч. были, преимущественно, миниатюры, наследу ющие традиции античной иллюзионистическо живописи. Напротив, принципы организации про- странства в композициях, в которых отсутствует иллюзия глубины, оставались долгое время «з скобками» искусствоведческих исследований. Исследования пространственных построений средневековой живописи XX столетия, в которые был внесен существенный вклад отечественных учёных, позволяют, опираясь на сохранившиеся памятники, наметить единую линию развития пространственных построений в позднеантичной книжной миниатюре и выделить основные типы организации пространства в иллюстрациях Именно эту цель преследует настоящая статья.

Взлёт искусства книжной миниатюры в позднеантичный период был связан, по мнению исследователей с технически и новые возможности для художников ${ }^{1}$. Речь идёт о постепенном переходе от папирусного свитка к пергаментному кодексу, который осуществился между II и $\vee$ веками нашей эры². Тем не менее до III-IV веков папирусные свитки оставались основными для рукописных текстов. Известно, что в античности существовала традиция иллюстрирования свитков, восходящая к египетским рукописям. ${ }^{3}$ Сохранившиеся фрагменты папирусов С миниатюрами, самый ранний из которых относится ко II веку до нашей эры ${ }^{4}$, позволяют утверждать, что иллюстрации античных свитков располагались непосредственно внутри узких текстовых колонок. Миниатюры буквально прерывают блок текста $и$ предлагают визуальный эквивалент той части повествования, рядом с которой располагается иллюстрация ${ }^{5}$. Тип композиций иллюстрированных свитков долгое время воспроизводился и в кодексах и существенным образом повлиял на развитие искусства оформления книги. Данному типу миниатюр соответствуют определенные особенности организации пространства.

Важной характерной чертой композиций иллюстрированных свитков является то, что образы расположены непосредственно на поверхности листа папируса. Действие, таким образом, раз-

1 Grabar Andre, Nordenfalk Carl. Le haut moyen age, du quaGieme au onzieme siecle. Geneve: Skira, 1957; Weitzmann K. 1970. C. 57

2 Weitzmann K. Illustraitions in Roll and Codex. Princeton University Press, 1970. C. 69-70.

Там же, С. 49 .

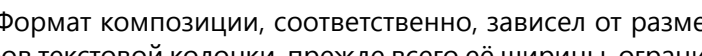
чивающей поле изображения слева и и справа. вивается вне какой-либо пространственной сре ды. Вероятнее всего, это связано с технической особенностью носителя: постоянная необходимость сворачивать папирус неминуемо привела бы к порче изображения и, в конечном итоге, к его разрушению ${ }^{6}$. Одновременно расположение изображений, как и текстовых элементов, непо средственно на плоскости листа усиливает связ текста и миниатюр. Подчеркивает связь текста и изображения то, что действие развивается по горизонтали слева направо. В фокусе внимания художника находятся образы персонажей, действующих лиц, которые, подобно словам в тексте, складываются в невербальное повествование.

Расположение в едином поле изображений и текста влечёт за собой то, что поверхность листа как бы подчиняет себе изображение, которое носит плоскостной характер. Такое отношение к художественной форме является противоположным по отношению к развитию иллюзионистических тенденций в монументальной фресковой живописи7 ${ }^{7}$ Можно предположить, что тесная связь образа с текстом в иллюстрации свитков требовала, чтобы характер изображения «поддержи вал» монолитность поверхности листа. Понятно и отсутствие светотеневой проработки объёмов, которая бы нарушала целостность поверхности листа, «продавливая» и ломая её. Напротив, плоскостной характер образов в полной мере соответствовал требованию сохранения и утверждения плоскости листа.

Заметим, однако, что плоскостной характер образов и отсутствие пространственно-предмет ной среды не означает отсутствия в композици ях определённых пространственных отношений. Так, весьма важным средством передачи пространства в иллюстрациях свитков является метод «наложения» одного изображения на другое Показывая, что одна фигура перекрывает другую, художник обозначает присутствие в композиции нескольких пространственных планов. Наглядным примером может быть фрагмент миниатюры с группой всадников из Коллекции Джонсона (IV—V вв.). Здесь пространственные планы формируются благодаря тому, что всадники, расположенные ниже на листе папируса, перекрывают фигуры других, расположенных выше.

6 Weitzmann K. Illustraitions in Roll and Codex. Princeton University Press, 1970, C. 52-53. Weitzmann K. Illustraitions in Roll and Codex. Princeton University Press, 1970. C. 53. 
Метод наложения тесно связан с другим приёмом, который можно обозначить как метод «сме щения по вертикали». Суть приёма состоит в том что плоскостные образы, соответствующие друг другу по масштабу, немного смещаются относительно друг друга по вертикали. Как известно, объект, расположенный ближе к человеку, на сетчатке глаза оказывается ниже, чем такой же объект, находящийся дальше. Наблюдательность античного художника позволяет использовать это смещение образов по вертикали на плоскости листа как художественный приём, указывающий на пространственные отношения между изображёнными фигурами. В качестве примера использования этого метода можно упомянуть иллюстрированный фрагмент пергаментного свитка из Баварской национальной библиотеки ${ }^{8}$ (IV в.) По мнению Вайцмана, сцена является иллюстрацией к Илиаде, и изображает момент, когда Талфибий и Эврибат уводят Бризеиду от Ахилла. Художник располагает одного из сопровождающих мужчин ниже, чем двух других персонажей. Таким образом, один персонаж оказывается на переднем плане, в то время как остальные смещаются на второй план, создавая иллюзию глубины пространства.

Приведённые примеры позволяют говорить о оом, что в античных иллюстрациях свитков с помощью указанных художественных приёмов выстраивались специфические пространственные отношения: система взаимного расположения плоскостно решённых образов без построения пространства, но создающая за счёт пространственных планов представление о его глубине. Эта система будет использоваться и в дальнейшем в дошедших до нас позднеантичных кодексах, в которых художники воспроизводят ту же схему построения пространства.

Это можно проследить на примере ряда дошедших до нас рукописей. Одной из них является так называемый Синопский кодекс из Национальной библиотеки Франции ${ }^{9}$ (VI в.). На листе 29 представлена сцена исцеления Христом слепого. Как и в иллюстрированных свитках, действие развивается вдоль плоскости листа по горизонтальной оси. Фигуры персонажей объединяет едва заметная тонкая линия позёма. Образы представлены в плоскостной манере: ноги, стопы персо-

8 Bauerische Staatsbibliotek. Munchen, gr. mon. 138 suppl. grec 1286, I. нажей, опирающиеся на условную линию позёма, изображены в профиль, в то время как торс развёрнуты в фас. Тем не менее в композиции ринилары как и во фрагментах иллюстрированных свитков, присутствует указание на пространственные отношения между персонажами Здесь также используется приём «наложения»; фигура одного слепого перекрывает фигуру дру гого, один из учеников скрывается за другими разом, в миниатюре Синопского кодекса воспроизводится система пространственных «планов», характерная для иллюстраций в свитках

Важной тенденцией миниатюр, воспроизводящих тип иллюстраций свитков в кодексах, являетс появление в них и развитие позёма, объединяющего фигуры персонажей. Так, если в Синопском кодексе позём представляет собой отвлечённую линию, то в сцене воскрешения Лазаря миниатюры листа 1 Евангелия из Россано ${ }^{10}$ (VI в.) линия позёма носит значительно менее отвлечённый характер. Художник передаёт неровности земли, где изгибающаяся линия позёма переходит в изображение скалы и гробницы. Таким образом, постепенно формируется пока ещё условный пространственный слой, намечающий единое пространство окружающей среды ${ }^{11}$. Ещё более заметна эта тенденция в нижнем регистре миниатюры листа 16 того же Евангелия из Россано, где линия позёма приоб ретает очертания холмистой поверхности земли представленной как будто «в разрезе».

Тем не менее, необходимо отметить, что на данном этапе позём остаётся только знаком плоскости. Подобно горизонтальной линии, которую писцы чертили для того, чтобы сохранить единство строчки, линия позёма объединяет образ композиции в единый рассказ. В центре внимания позднеантичного художника является на глядность этого рассказа, сообщение зрителю необходимой для понимания развития сюжет информации о действующих лицах и окружающих их предметах. В определённых случаях принци наглядности повествования требует от мастера передачи глубины в изображении отдельного объекта, которым чаще всего выступает архитек-

10 Museo Diocesano di Arte Sacra di Rossano, Codex Rossanensis

11 Ещё более явным становится эта тенденция в нижнем ре гистре миниатюры на странице 16 того же Евангелия и Россано, где линия плоскости земли приобретает очерта-
ния небольшого холма, который мы видим словно «в разрезе тура. Таким образом, возникает противоречие между объединяющей образы горизонтальной линией позёма и общим плоскостным характером композиции, с одной стороны, и требованиями принципа наглядности повествования, с другой. Мастера оказываются в таких случаях перед сложной задачей совмещения двух этих противоречивых моментов.

Один из вариантов решения этой задачи соединение в изображении объекта нескольких различных ракурсов. Так, в миниатюре листа 13 Евангелия из Россано (рис. 1, 2.), посвящённой исцелению слепого, изображенная в правой части «купальня» представлена как параллелепипед. Художник показывает верхнюю часть купели с более высокой точки зрения, изображая её в системе аксонометрии. Это необходимо, по всей видимости, для того, чтобы показать гладь воды и объём купели, необходимый для понимания её назначения. В то же время все остальные образь композиции подчинены принципу плоскостности развиваются вдоль горизонтальной линии, обозначающей поверхность земли. Соответственно для того, чтобы передать устойчивость купели художник изображает нижнюю часть плоскостно, для чего непропорционально, как кажется, удлиняет её вертикальную сторону. Таким образом, в одном объекте за счёт комбинации нескольких точек зрения, передается объём, глубина и, одновременно, все образы композиционно выстраиваются на одной горизонтали. Плоскость листа не нарушается. Такие приёмы композиционного построения встречаются всё чаще с VI века.

Другой вариант - присоединение трёхмерного изображения к линии позёма без искажений и уплощение образа на уровне колористического решения. В качестве примера можно вспомнить миниатюру 4v Венской Книги Бытия ${ }^{12}$ (I пол. VI века), посвящённую обещанию, данному Богом Аврааму о его многочисленном потомстве. В левой части верхнего регистра композиции представлен спящий на ложе Авраам. Ложе изображено художником в системе аксонометрии без искажений. Боковая плоскость параллелепипеда развивается по диагонали, дальний край смещён вверх по вертикали. Естественное расположение предмета требует плоскости поверхности, соответственно уходящей в глубину. Напротив, художник достаточно механически присоединяет торцевую сто-

12 Wien, Österreichische Nationalbibliothek, Cod. Theol. gr. 31 рону ложа к горизонтальной линии позёма, в то время как её длинная сторона оказывается не связанной с плоскостью. Возникшее противоречие между трехмерностью изображённого предмета обусловленной принципом наглядности, и общим плоскостным характером композиции решаетс художником, в отличие от предыдущего приме ра, не за счёт искажения формы предмета путём суммирования зрительных впечатлений а за счёт «уплощения» в изображении кровати и колори стического решения локальными пятнами. Объём предмета угадывается, но не поддерживается светотеневым решением. В результате задача решена: художник передал трёхмерность ложа и не нарушил монолитности плоскости листа пергамента.

Таким образом, оба варианта решения описанного противоречия предполагают известную «разорванность», нарушение единства пространственной логики внутри композиций. Мастер идёт на эти искажения для того, чтобы соответствовать важнейшему принципу наглядности повествования. Анализируя такую гетерогенность пространства позднеантичных миниатюр, можно вспомнить мысль Э. Панофски, высказанную в его статье «Перспектива как «символическая форма», о принципиальной разорванности, несистематичности пространства в античном искусстве ${ }^{13}$. Великий немецкий исследователь писал об античных композициях, в которых формиру ется иллюзия глубины пространства. Тем не менее представляется, что этот принцип актуален и для традиции свитковой иллюстрации.

Итак, приведённые примеры миниатюр в свит ках и кодексах позволяют говорить о специфическом типе организации пространства, характерном для традиции иллюстрированных свитков. Тесная связь миниатюр данного типа с текстом с одной стороны, определяет плоскостной характер образов и их развитие по горизонтали наподобие текстовой строки. С другой стороны, необходимость создания максимально точного изобразительного эквивалента тексту определяет необходимость ряде случаев передачи глубины путём выстраи вания плоскостных образов в систему пространственных планов или включения в композицию элементов трёхмерного изображения, не нарушающих плоскостного характера композиций.

13 Панофский Э. Перспектива как «символическая форма Готическая архите
сика, 2004. С. 48. 
Анализируя пространственные построения в книжной миниатюре эпохи поздней античности, нельзя не упомянуть о таком важнейшем процессе, как постепенная эмансипация изображения от текстовой колонки. Система иллюстраций свитка, перенесённая в кодекс, трансформируется. Увеличение размера текстового блока влечёт за собой увеличение увеличения размера иллюстрации. Композиции, существовавшие ранее отдельно, соединяются в одну ${ }^{14}$, иногда располагаются в несколько уровней. Процесс отделения изображения от текста тесно связан с развити ем пространственных построений. Так, в отдельных памятниках две разнесённые во времени и пространстве сцены, расположенные одна над другой, соединяются путём расширения позёма. Примером такого соединения может служить ми ниатюра листа 9r (рис. 3.) Венской Книги Бытия. Несмотря на несколько механический характер соединения двух сцен, нельзя не отметить, что условная линия позёма превращается в единую плоскость поверхности земли, на которой располагаются персонажи. Следующим важным этапом на пути эмансипации изображения от текста является отделение образа рамкой. Выделение иллюстрации в отдельное пространство освобождае её от доминирования плоскости листа, зрительно уплощающей изображение. Вслед за этим важным шагом следует живописное решение фона. Важно отметить, что, как заметил Курт Вайцман этот фон трактуется достаточно плоскостно ${ }^{15}$. Coздание иллюзии пространства происходит путём добавления (порой «несколько механического», по выражению Вайцмана) к площадке позёма плоского задника, который достаточно условно изображает удалённую от зрителя часть среды. Таким образом, действие происходит в узкой полосе пространственного слоя, на своего рода сцене, «зажатой» между прозрачным «экраном» поверхности листа и плоским фоном, напоминающим театральные декорации.

Примером такой организации пространства являются миниатюры Амброзианской Илиады (кон. V - нач. VI в.). На листе $42 \mathrm{v}$ представлено жертвоприношение Ахилла (рис. 4, 5). Действие разворачивается на вытянутой по горизонтали охристо-жёлтой полосе земли Сзади оно огра14 Weitzmann K. Illustraitions in Roll and Codex. Princeton University Press, 1970. C. 84

Weitzmann K. Illustraitions in Roll and Codex. Princeton Uni-

16 Mersity Press, 1970. C. 99. поверхности земли и фоном отсутствует чёткая граница. Так, в сцене жертвоприношения Саула, представленной на листе 2 Кведлинбургской Италы, нижняя жёлто-охристая полоса, на которой разворачивается действие миниатюры, плавно соединяется с фоном. Задний план формируется художником из нескольких плавно перетекающих друг в друга цветовых полос. Этот приём позволяет художнику создать ощущение плавно уходящего вдаль пространства, в то же время не создавая понимания его глубины, так как задний план не содержит в себе никакого намёка на предметную среду, очертаний предметов или линии горизонта. Из-за этого достаточно сложно говорить о том, что античный художник преодолевает плоскостное решение фона, скорее фон миниатюры напоминает живописные декорации, на которых изображено уходящее вдаль пространство, при том, что сами декорации остаются плоскими.

Необходимо отметить, что авторы иллюзионистических миниатюр двух великолепных манускриптов решали весьма разнообразные пространственные задачи. В миниатюрах Ватиканского Вергилия присутствуют изображения интерьеров, как, например, в сцене смерти Дидоны на листе 41r. В интерьерных сценах на листах 40r и 41r художник изображает потолок в характерной «античной» перспективе ${ }^{20}$ : параллельные прямые сходятся относительно друг друга, но не идут в единую точку схода. В той же рукописи есть примеры пейзажей с панорамным обзором, как в миниатюре на листе 42r. Тем не менее во всех этих случаях сохраняется та же система: действие разворачивается между экраном листа и плоским фоном.

Таким образом, можно заключить, что в мини атюрах рукописей, созданных на излёте существования Римской империи, присутствуют примерь создания иллюзии пространства в соответствии с определёнными принципами. В то же время эти принципы значительно менее жёсткие, чем в математически выстроенной ренессансной перспективе. В позднеантичных миниатюрах нет математически выверенной перспективной сетки, которая «накладывается» на изображение и подчиняет себе все элементы композиции. Иллюзия пространственного слоя формируется с помощью

20 Панофский Э. Перспектива как «символическая форма». классика, 2004. С. 50. ряда художественных приёмов, нацеленных скорее на создание иллюзии объёмности фигур персонажей и окружающих их предметов, нежели на формирование жёстко структурированного пространства. В этой связи нельзя не вспомнить ещё раз мысль Эрвина Панофски о несистема тичности пространства в античном искусстве. Немецкий исследователь отмечает, что в иллюзионистических античных композициях присутствуют постоянные «сбои». Эта «разорванность пространства связана, по мысли Панофски, с тем, что классическое искусство Античности, заложившее фундамент не только для позднеантичного, но и средневекового искусства, было «искусством чистой телесности» ${ }^{21}$. Эпоха эллинизма, по мыс ли Панофски, расширила поле зрения художника Мастера начинают изображать помимо предметов «окружающее и объединяющее их пространство». Тем не менее «художественное мышление всё ещё настолько привязано к отдельно взятым предметам, что пространство воспринимается не как нечто обеспечивающее и подчёркивающее различие между телом и нетелом, но до некоторой степени лишь как то, что остаётся в промежутке между телами ${ }^{22}$,.

Таким образом, в античном искусстве акцент смещён на изображение тела. Действительно, в приведённых выше примерах миниатюр позднеримских рукописей иллюзия пространства возникает благодаря определённым художественным приёмам, направленным в большей степени на изображение тел, объектов, передачу их взаимного расположения, нежели окружающей их среды. Этот принцип аспективы, судя по сохранившимся древнеримским копиям, был характерен для монументальной живописи Древней Греции, однако в миниатюрной живописи поздней Античности он претерпевает свои изменения. Фокус внимания на изображение отдельных объектов, «тел», отражается на характере передачи пространства. Здесь взаимное расположение фигур в пространстве не подчинено строго определённому модулю. Соответственно, по мере удаления от переднего плана миниатюры в глубину изображения, размеры объектов часто не уменьшаются. Так, в некоторых миниатюрах Ватиканского Вергилия, когда необходимо было

21 Панофский Э. Перспектива как «символическая форма» Готическая архитектура и схоластика. Спб, Азбука-классика, 22 TaM жe, c. 48
17 Weitzmann K. Illustraitions in Roll and Codex. Princetol
versity Press, 1970 . C. 100. .
18 Staatsbibliothek zu Berlin, Cod. theol. lat. fol. 485.
19 Biblioteca Apostolica Vaticana, Vat. lat. 3225. 
показать широкую панораму города или целого острова, как, например, на листе $27 r$, художник расширяет плоскость «сцены» до верхнего края листа. Казалось бы, можно ожидать, что расши рение плоскости поверхности позволит передать активное развитие пространства в глубину, однако античный мастер избегает углубления пространства и стремится сохранить единый масштаб изображаемых объектов. Дома и стены, расположенные в верхней части изображения и, по всей видимости, достаточно удалённые от зри теля, показаны в том же масштабе, что и расположенные на переднем плане. Таким образом расширение пространственного слоя не решает проблему глубины поля действия. Пространство миниатюры всё равно остаётся неглубоким.

Концентрация внимания художника на изображении отдельных объектов предметного мира тесно связана с субъективностью изображения пространства, о которой говорит Э. Панофски. В некоторых миниатюрах Ватиканского Вергилия эта субъективность приводит к тому, что определённые элементы композиций изображаются отдельно, в отрыве от единой пространственной логики. Ряд отечественных исследователей видят в подобных «искаженияХ» стремление изобразить предмет в наиболее выгодном ракурсе, таким образом, чтобы информация о нём была передана максимально полно ${ }^{23}$. Действительно, в композиции 17r расположенные на заднем плане море, граница береговой линии и остров переданы с более «высокой точки зрения, буквально сверху вниз. В то же время храм на острове изображён с фронтальной точки зрения, как и деревья, расположенные за ним на верхней границе плоскостного пятна острова. Подобное соединение плоскостного и трёхмерного изображения встречается неоднократно: можно вспомнить лист $6 r$, где внутри пространственного слоя неожиданно появляется разрушающее единство пространства изображение озера, из которого вытекает река: река «лежит» в плоскости поверхности в то время как озеро представлено не в ракурсе, а совершенно фронтально, как если бы мы смотрели на него сверху вниз. Также субъективность пространства проявляется в несоблюдении единства масштабности элементов композиции. В миниатюре 19r фигуры воинов несообразно велики 23 Флоренский П. Сочинения в четырёх томах. Т. З. Обратная перспектива. М.: Мысль, 2000. С. 46-98; Раушенбах 5.В. Пространственные построения в древнерусской жи-
вописи. М.: Наука, 1975; Успенский Б.А. Семиотика искус-

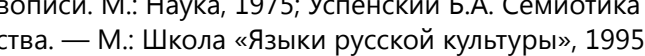

не только по сравнению со стенами города, но и с Троянским конём.

Таким образом, несмотря на то, что в позднеантичных пространственных миниатюрах была выработана определённая система построения пространства, эта система была достаточно гибкой и предполагала известную субъективность. Эта субъективность постепенно усиливается, начиная с середины $\mathrm{V}$ века ${ }^{24}$. С этого времени в книжной миниатюре происходит постепенный переход от отношения к образу как формируемой на плоскости иллюзии видимой реальности к образу как изобразительной единице, интегрирующей в себе целый комплекс знаний об объекте. Иными слоавтора, разнесенные во времени и пространстве. Соответственно, изображение нередко соединяе в себе различные точки зрения и разные ракур сы, что ведёт к его уплощению. Художественные средства, направленные на передачу объёма, такие как лепка формы светотенью, падающие тени соответствие поворота стоп плоскости поверх ности земли - все эти приёмы оказываются ненужными и постепенно уходят. Особое значение приобретает контур как объединяющее компози ционное начало, соединяющее различные ракурсы воедино. Образ как сумма знаний об объекте предполагает не только поиски наиболее выразительного ракурса, но и выражения лица, наиболее характерно отражающее представление нём как целостной личности, его внутреннем мире. Таким образом, принцип суммирования зрительных впечатлений в пространстве и времени по зволяет сообщить зрителю значительно больше информации об объекте, чем повторение на изобразительной плоскости единичного впечатлени от объекта в определённый момент времени. В известном смысле, можно говорить о том, что логи ка развития античного искусства не прерывается. Как и в античной иллюзионистической живописи в фокусе внимания находится объект изображения. Смещается акцент с субъективности единич ного взгляда на объект к большей объективности стремлению изобразить предмет так, как его знает художник, а не так, каким он видится.

Описанные изменения, происходившие, по всей видимости, постепенно, с разной скоростью в разных областях, можно проследить на примере ряд памятников переходного периода. Необходимо за-

24 Weitzmann K. Illustraitions in Roll and Codex. Princeton University Press, 1970. C. 56 метить, что, прежде всего, изменения коснулись характера изображения персонажей. Примером может послужить миниатюра со сценой Дидоны и Энея на пиру из Римского Вергилия 25, рукописи середины $\vee$ века, в которой впервые прослеживаются черты перехода к новой изобразительной системе. Стремясь передать расположение центральных персонажей миниатюры, художник объединяет несколько различных точек зрения: стол изображается с высокой точки зрения, как бы сверху вниз, а торсы персонажей, напротив, развёрнуты анфас и расположены вокруг стола. Лица главных действующих лиц для большей наглядности переданы анфас, их торсы увеличены относительно ног. Художник акцентирует внимание на главном: показывая вытянутую по направлению к столу руку левого персонажа, мастер изображает только кисть и предплечье, которые, по всей видимости, представлялись ему достаточными для передачи информации о действии героя. При этом плечо «опускается» художником как неинформативная деталь, которая могла бы помешать ритмическому единству и целостности изображения. Указанные искажения приводят к зрительному уплощению образов. Способствует этому впечатлению и характер изображения одежд персонажей, которые представляют собой локальные цветовые пятна, поверх которых накладывается линейный ритм складок.

Тем не менее, важно отметить, что описанные «искажения» в изображениях персонажей не разрушают основу системы пространственного слоя. Действие разворачивается на узкой горизонтальной площадке, ограниченной вертикальной плоскостью стены. Благодаря смещению композиционных элементов по вертикали формируется система планов: фигуры рабов расположены ближе, на переднем плане, далее - стол, а вдоль горизонтальной плоскости стены вытянулись фигуры возлежащих. Расположение фигур слуг, которые перекрывают горизонтальное ложе, свидетельствует о том, что они находятся ближе, и это, в свою очередь, зрительно выдвигает их на передний план. Таким образом, можно говорить о том, что в миниатюре Римского Вергилия сформирован пространственный слой. Однако стремление к суммированию нескольких точек зрительных впечатлений и общее уплощение образов приводит к тому, что ощущение пространственной динамики существенным образом ослабевает.

25 Biblioteca Apostolica Vaticana, Vat. lat. 3867.
Значимым изменением в организации пространства миниатюры становится соединение пространства, в котором развивается действие заднего плана. Так, в Евангелии Раббула ${ }^{26}$ (VI в.) на листе 14r, евангелисты, окружающие восседа ющего на троне Христа, изображены на зелёном поле, покрывающем своим ковром всё поле ми ниатюры. Художник не даёт никакого намёка на границу горизонтальной плоскости и фона. В то же время противопоставление горизонтальной поверхности земли, уходящей в глубину, и вер тикальной плоскости задника подразумевает ся, и это осуществляется некоторыми приёмами и деталями. Фигуры евангелистов анатомически пропорциональны, они освещены из одной точки (справа от каждой фигуры падает тень), стопы персонажей «стоят» на одной плоскости, то есть повернуты соответственно друг другу так, что зрительно угадывается плоскость, на которой расположены ноги. Кроме того, здесь также использован приём смещения по вертикали две фигуры, расположенные на листе ниже, вос принимаются ближе к зрителю, чем те, которые находятся выше. Таким образом, создаётся впечатление, что плоскость «сцены» как будто плавно перетекает в вертикаль фона

Напротив, в другой миниатюре Евангелия Раббула 1r, в сцене, посвящённой Пятидесятнице, ощущение пространственной динамики внутри изображения пропадает, хотя представленные персонажи расположен на таком же фоне в виде

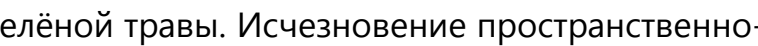
го слоя связано с соединением при построении пространства двух точек зрения. С одной стороны фигуры апостолов расположены по краю круглого поля, так что кажется, что сцена воспринимается с высокой точки зрения. С другой стороны, сами фигуры апостолов изображены строго фронтально. Таким образом, применение принципа сум мирования зрительных впечатлений приводит к тому, что фигуры персонажей кажутся как будто вырезанными и наклеенными на плоскость миниатюры. Соответствует этому впечатлению то, что апостолы, будучи изображёнными анатомически верно, совершенно лишены светотеневой градации и поэтому выглядят плоскими. Усиливают это эффект густые контурные линии, окружающие фигуры. Между персонажами присутствуют определённые пространственные отношения, однако они 
скорее угадываются, нежели изображаются. Расположенные ниже фигуры апостолов перекрывают другие, расположенные несколько выше, и выступают на первый план миниатюры.

Таким образом, можно говорить, что в кодексах в позднеантичных миниатюрах, отделённых от текста рамой, происходит возвращение к системе пространственных планов. В известном смысле этот процесс можно рассматривать в контексте развития общей тенденции позднеантичного искусства, отмеченной Панофски: интереса к изображению объектов, порой в ущерб единству пространственной логики. Соответственно, эта тенденция в трактовке образов приводит к усилению субъективности в передаче пространства, а затем - к отказу от задачи создавать и иллюзию пространства. Для передачи пространственных отношений между образами достаточно обозначить эти отношения, указать на них, но не изображать. Для этого вполне достаточными оказываются художественные средства, которые использовались для обозначения пространственных отношений в иллюстрациях свитков, метод «наложения» образов друг на друга и метод «смещения по вертикали».

Приведём несколько примеров позднеантичных миниатюр с пространством, выстроенным планами. Это одна из небольших миниатюр, посвященных Страстям Христовым на листе $125 \mathrm{r}$ Евангелия святого Августина ${ }^{27}$ (VI в.). В одном из квадратных клейм верхнего ряда, посвящённом Тайной Вечери, пространство организовано планами (рис. 6.). Христос и апостолы сидят за столом: фигуры персонажей изображены фронтально, а стол представлен с высокой точки зрения. В то же время выстраивается система пространственных планов: стол закрывает от нас фигуры персонажей и как бы выходит вперед (рис. 7.). В свою очередь, апостолы изображены в два ряда, так что передний ряд закрывает от нас фигуры сидящих сзади и уводит их на задний, третий план.

27 Cambrdige, Corpus Christi College, Lib. MS. 286.
Ещё одним примером памятника, чьи миниатюры выстроены в соответствии с принципом плановости, является Пентатевк Ашбернхема 28 (VI - нач. VII в.). Так, в верхней части миниатюры листа $65 \mathrm{r}$ «Египтяне, оплакивающие своих первенцев» изображённые достаточно условно персонажи, как будто парят на фоне построек. Фигуры лишены связи с плоскостью, кажется, они как бы вырезаны и наложены поверх архитектурного фона, заполняющего всё поле миниатюры. Таким образом, формируется два плана: на переднем разворачивается действие, а второй представляет собой развернутую архитектурную композицию, обозначающую место действия. Подобная система организации планового пространства будет чрезвычайно важна для средневекового искусства миниатюры. В особенности она будет востребована в иллюстрациях рукописей Романской эпохи, в которых плоскостные образы формируют сложную, многоступенчатую систему пространственных планов ${ }^{29}$.

Таким образом, в позднеантичной книжной миниатюре можно выделить три основных типа построения пространства. Во-первых, традиция свитковой иллюстрации внутри текстового блока предполагает плоскостной характер композиций, развивающихся по принципу фриза вдоль горизонтальной линии. Во-вторых, появление рамки позволило создавать композиции, в которых действие развивается внутри пространственного слоя, ограниченного, с одной стороны, плоскостью листа, а с другой, - плоским задним планом. В-третьих, под влиянием общего вектора развития искусства в V-VII вв. отделённые от текста рамкой миниатюры возвращаются к организации композиции как системы пространственных планов.

28 Bibliothèque nationale de France, MS nouv. acq. lat. 2334.

29 Pächt O. Buchmalerei des Mittelalters: eine Einführung. Prestel-Verlag, 1984. S. 43.

\section{БИБЛИОГРАФИЯ:}

1. Жёгин Л.Ф. Язык живописного произведения. - М.: Искусство, 1970.

2. Раушенбах Б.В. Пространственные построения в древнерусской живописи. - М.: Наука, 1975.

3. Успенский Б.А. Семиотика искусства. - М.: Школа «Языки русской культуры», 1995.

4. Флоренский П. Сочинения в четырёх томах. - Т. 3. Обратная перспектива. - М.: Мысль, 2000. С. 46-98.
5. Grabar A., Nordenfalk C. Le haut moyen age, du quatrieme au onzieme siecle. - Geneve; Skira, 1957.

6. Weitzmann K. Illustraitions in Roll and Codex. Princeton University Press, 1970.

7. Pächt O. Buchmalerei des Mittelalters: eine Einführung. — Prestel-Verlag, 1984. S. 43. 